\title{
Analisis Potensi Penerimaan Pajak Reklame di Kota Jambi Periode 2014-2016
}

\author{
Muhammad Syukri \\ Fakultas Ekonomi Universitas Batanghari Jambi \\ Correspondence email: msukri126@gmail.com
}

\begin{abstract}
Billboard tax is one of the many taxes in the city of Pekanbaru where its existence is very important as a source of Local Revenue (PAD). The existence of this advertisement tax is expected to be the main source of revenue given the conditions and potential of the area owned by the city of Pekanbaru. However, in its realization, the existence of this advertisement tax is less than optimal, where the value and growth from 2007 to 2011 decreased significantly even with a value that did not reach the specified target. In addition, the difference between the target set by the government and the realization of the advertisement tax obtained by the Pekanabru city Dispenda indicates the possibility that the potential of the existing advertisement tax has not been optimally explored. The results showed that the advertisement tax potential was very large, far above the realization value of advertisement tax revenue from 2007 to 2012. The research results also showed that the advertisement tax potential that had not been optimally explored, there were still potential tax unreached and there were several things that were need to be a correction related to advertisement tax in the city of Pekanbaru, such as a strict management and supervision system in the field so that fraud does not occur in the future.
\end{abstract}

Keywords: Advertisement Tax and PAD (Local Original Revenue)

\section{PENDAHULUAN}

Negara Indonesia merupakan negara yang menganut sistem otonomi daerah dalam menjalankan pemerintahannya. Otonomi daerah sendiri merupakan salah satu wujud reformasi terhadap penyelenggaraan pemerintahan daerah provinsi/kabupaten/kota demi mengantisipasi berbagai tuntutan perubahan ketatanegaraan baik secara sosial maupun politik yang berasal dari dalam negeri maupun luar negeri. Undang-undang Nomor 22 Tahun 1999 tentang pemerintahan daerah menyatakan dalam penyelenggaraan otonomi daerah dipandang perlu untuk menekankan pada prinsip-prinsip demokrasi, peran serta masyarakat, pemerataan dan keadilan, serta memperhatikan potensi dan keanekaragaman daerah. Pajak daerah dan retribusi daerah merupakan salah satu sumber pendapatan daerah yang penting guna membiayai pelaksanaan pemerintahan daerah, untuk meningkatkan pelayanan kepada masyarakat dan kemandirian daerah, perlu dilakukan perluasan objek pajak daerah dan retribusi daerah dan pemberian diskresi dalam penetapan tarif. Berbagai macam jenis pungutan pajak daerah yang menjadi sumber pendapatan negara, seperti Pajak Penghasilan, Pajak Pertambahan Nilai, Pajak Penjualan Atas Barang Mewah, Pajak Bumi dan Bangunan, Pajak Hotel, Pajak Restoran, Pajak Hiburan, Pajak Reklame, Pajak Penerangan Jalan dan lain-lain. Pentingnya pajak sebagai sumber pembiayaan pembangunan telah ditetapkan dalam berbagai produk perundang-undangan pemerintah. Pajak sebagai penerimaan daerah tampaknya sudah jelas bahwa apabila pajak ditingkatkan maka penerimaan daerah pun meningkat, sehingga daerah dapat berbuat lebih banyak untuk kepentingan masyarakat. Sebagai pemerataan pendapatan masyarakat, kenyataan menunjukkan bahwa dikalangan masyarakat masih banyak terdapat kesenjangan antara warga negara yang kaya dan yang miskin. Pajak adalah salah satu alat untuk dapat meredistribusi pendapatan dengan cara memungut pajak yang lebih besar bagi warga yang berpendapatan tinggi dan memungut pajak yang lebih rendah bagi warga yang berpendapatan lebih kecil.

Kota Jambi merupakan Ibukota dari Provinsi Jambi yang menjadi pusat pembangunan di Provinsi Jambi. Dengan perkembangan tersebut, banyak investor atau pengusaha yang tertarik untuk menanamkan modal sehingga semakin banyak usaha-usaha atau perindustrian yang ada di Kota jambi. secara tidak langsung hal ini berakibat pada penerimaan pajak reklame, karena semakin banyak jumlah usaha, atau jumlah industri maka semakin banyak juga konsumen yang menggunakan jasa reklame. Jumlah Perusahaan berpengaruh terhadap penerimaan pajak reklame sehingga perusahaan dapat berkembang mempromosikan produknya baik itu usaha kecil, menengah, maupun besar yang ada di Kota Jambi. Bertambahnya jumlah Perusahaan yang memasang reklame meningkatkan objek pajak, sehingga penerimaan daerah juga meningkat.

\section{Pengertian Reklame}

Menurut kamus umum Bahasa Indonesia reklame adalah pemberitahuan kepada umum tentang barang dagangan, dengan pujian atau gambar dan sebagainya, dengan tujuan agar dagangan tersebut lebih laku. Pengertian 
reklame menurut Peraturan Daerah Nomor 14 Tahun 2008 tentang Tata Cara Perizinan Reklame menyatakan bahwa, reklame adalah benda, alat, perbuatan atau media yang menurut bentuk dan corak ragamnya untuk tujuan komersial, dipergunakan untuk memperkenalkan, menganjurkan atau memujikan suatu barang, jasa atau orang, ataupun untuk menarik perhatian umum kepada suatu barang, jasa atau orang yang ditempatkan atau dapat dilihat, dibaca, dan/atau didengar dari suatu tempat oleh umum kecuali yang dilakukan oleh pemerintahan. Dari pengertian reklame diatas, maka definisi izin reklame secara sederhana adalah izin yang dikeluarkan pemerintah daerah untuk penyelenggaraan reklame. Dalam Peraturan Daerah (PERDA) Kota Jambi No 05 Tahun 2011 pasal 1 tentang reklame dijelaskan bahwa : "Pajak reklame adalah benda, alat, perbuatan atau media yang menurut bentuk dan corak ragamnnya untuk tujuan komersial memperkenalkan, menganjurkan, mempromosikan, atau untuk menarik perhatian umum terhadap barang, jasa, orang atau badan, yang dapat dilihat, dibaca, didengar, dirasakan atau dinikmati oleh umum.

\section{Dasar Pengenaan dan Tarif Pajak Reklame}

Menurut Peraturan Daerah (Perda) No 2 Tahun 2005 pasal 27 ayat 1 menjelaskan besarnya pajak reklame dihitung dengan cara mengalihkan tarif pajak sebesar $20 \%$ (dua puluh persen), khusus untuk reklame rokok dan minuman beralkohol dikenakan tarif khusus sebesar 25\% dengan dasar pengenaan pajak. menjelaskan Nilai Sewa Reklame Sebagaimana dimaksud dengan memperhatikan faktor jenis, bahan yang digunakan, lokasi penempatan, jangka waktu penyelenggaraan, jumlah dan ukuran media Reklame.

Nilai Sewa Reklame sebagai dasar pengenaan pajak dari masing - masing jenis reklame dihitung dengan menggunakan rumus : Jenis Reklame x Luas Reklame x Jumlah Sisi Reklame x Indeks Lokasi (Nilai Strategis) $\mathrm{x}$ Jangka Waktu Pemasangan x Tarif pajak Reklame.

\section{METODE}

Dalam penelitian ini data yang digunakan adalah data sekunder yang merupakan data berkala yang sudah tersedia, yang telah dikumpukan oleh instansi terkait terlebih dahulu. Data sekunder tersebut meliputi: Penerimaan Pajak Reklame Kota Jambi, berdasarkan jenisnya; penerimaan Pajak daerah kota Jambi; data-data lain yang berkaitan dengan penelitian ini. Data-data sekunder tersebut diperoleh dari : BPPRD Kota Jambi dan BPS Provinsi, Kota Jambi dan Disperindag Prov. Jambi

\section{Metode Analisis}

Data yang digunakan dalam mencari potensi yaitu data kuantitatif. Analisis untuk menjawab permasalahan pertama cara menganalisis potensi pajak reklame digunakan rumus sebagai berikut:

Potensi Reklame (PPrk) = R X S X D X Pr

Keterangan : R : Jumlah Papan Reklame; S : Jumlah Ukuran Potensi; D : Kurun Waktu; Pr : Tarif Pajak Reklame Perhitungan dilakukan dari tahun 2014 hingga 2016. Tarif yang digunakan pada tahun 2014-2016 yaitu sebesar 20\% dengan menggunakan Perda nomor 2 tahun 2005 tentang pajak reklame, Sedangkan untuk reklame rokok dan minuman beralkohol dikenakan tarif khusus sebesar 25\%. Perhitungan yang dilakukan penulis dengan memperhatikan jumlah papan reklame yang ada di Kota jambi.

\section{HASIL}

Analisis Potensi Pajak Reklame di Kota Jambi

Tabel 1

Target dan Realisasi Penerimaan Pajak reklame Tahun 2010-2016

\begin{tabular}{lccrr}
\hline No & Tahun & Target (Rp) & Realisasi (Rp) & Persentase (\%) \\
\hline 1 & 2010 & 3.752 .500 .000 & 4.152 .927 .493 & 110,67 \\
2 & 2011 & 4.277 .500 .000 & 4.396 .409 .040 & 102,77 \\
3 & 2012 & 4.400 .000 .000 & 5.306 .793 .041 & 120,60 \\
4 & 2013 & 5.500 .000 .000 & 5.566 .425 .497 & 101,20 \\
5 & 2014 & 7.500 .000 .000 & 5.270 .552 .970 & 70,27 \\
6 & 2015 & 10.000 .000 .000 & 6.000 .440 .224 & 60,00 \\
7 & 2016 & 10.000 .000 .000 & 8.475 .131 .873 & 84,75 \\
& & & & $\mathbf{9 2 , 8 9}$ \\
\hline
\end{tabular}

Sumber: BPPRD Kota Jambi

Dapat dilihat dari Tabel 1 diatas bahwa penerimaan pajak reklame kota Jambi nilainya cukup besar, akan tetapi dari tabel tersebut bahwa nilainya tidak stabil. Dapat dilihat tahun 2014 hanya mencapai Rp.5.270.552.970 atau sekitar 70,27 persen jauh dari target yang diharapkan sedangkan pada tahun 2015 kembali mengalami penurunan dari target yang ditetapkan Rp.10.000.000.000tapi hanya tercapai Rp.6.000.440.224 atau sekitar 60 persen sampai pada 
tahun 2016 apa yang telah ditargetkan pemerintah realisasinya belum dapat tercapai secara optimal meskipun ada kenaikan realisasinya menjadi Rp.8.475.131.873atau sekitar 84,75 persen.

Tabel 2

Jumlah Wajib Pajak Reklame Pada Tahun 2010-2016

\begin{tabular}{|c|c|c|c|c|c|c|c|c|}
\hline \multirow{2}{*}{ No } & \multirow{2}{*}{ Jenis Reklame } & \multicolumn{7}{|c|}{ Tahun } \\
\hline & & 2010 & 2011 & 2012 & 2013 & 2014 & 2015 & 2016 \\
\hline 1 & Megatron & & 1 & 1 & 2 & 2 & 3 & 5 \\
\hline 2 & Bando & & 64 & 62 & 73 & 85 & 87 & 96 \\
\hline 3 & Bilboard & & 1.065 & 1.412 & 1432 & 1.586 & 1.809 & 2.645 \\
\hline 4 & Neon Box & & 238 & 243 & 267 & 295 & 320 & 378 \\
\hline 5 & Spanduk & & 797 & 819 & 812 & 821 & 970 & 986 \\
\hline 6 & Baliho & & 241 & 232 & 245 & 240 & 560 & 821 \\
\hline \multicolumn{2}{|c|}{ Jumlah } & 1.749 & 2.406 & 2.769 & 2.831 & 3.029 & 3.749 & 4.931 \\
\hline
\end{tabular}

Sumber: BPPRD Kota Jambi

Dalam Peraturan Daerah Kota Jambi Nomor 2 Tahun 2005 Tentang Pajak Reklame menyebutkan bahwa perhitungan besaran pokok pajak reklame yang terutang dengan cara mengalikan tarif dengan dasar pengenaan pajak atau nilai sewa reklame dengan rumus: Sewa Pajak Reklame = Jenis Reklame x Luas reklame x Jumlah sisi reklame $\mathrm{x}$ Nilai strategis lokasi x Jangka waktu x Tarif reklame

Tabel 3

Rata-Rata Nilai Sewa Objek Pajak Reklame Tahun 2014-2016

\begin{tabular}{lrrrrrrrr}
\hline \multicolumn{1}{c}{ Jenis Reklame } & Harga (Rp) & P(M) & L(M) & Jml Sisi & NSL & Waktu & Trf Pjk (\%) & Jumlah (Rp) \\
\hline Megatron/ Videotron & 750.000 & 6 & 3 & 1 & 6 & 1 tahun & 20 & 16.200 .000 \\
Reklame Bando & 400.000 & 8 & 3 & 2 & 6 & 1 tahun & 20 & 23.040 .000 \\
Reklame Bilboard & 300.000 & 7 & 3 & 2 & 6 & 1 tahun & 20 & 15.120 .000 \\
Reklame Neon Box & 250.000 & 2 & 2 & 2 & 6 & 1 tahun & 20 & 2.400 .000 \\
Reklame Spanduk & 1.500 & 3 & 1 & 1 & 6 & 1 hari & 20 & 5.400 \\
Reklame Baliho & 2.250 & 4 & 2 & 1 & 6 & 1 hari & 20 & 21.600 \\
\hline
\end{tabular}

Sumber: Data diolah BPPRD Kota Jambi

Setelah diketahui masing-masing jenis besaran nilai sewa pajak reklame, barulah dimasukan rumus menghitung potensi pajak reklame menurut Kesit Bambang Prakosa (2005) bahwa potensi pajak reklame yang dapat diraih adalah dengan rumus : Potensi Reklame (PPrk) = R X S X D X Pr

Keterangan: R: Jumlah PapanReklame (Unit); S: Jumlah UkuranPotensi (Rp); D: KurunWaktu (hari/minggu/bulan/tahun); Pr : Tarif PajakReklame (persen)

Tabel 4

Hasil Perhitungan Potensi Pajak Reklame Tahun 2014

\begin{tabular}{lrrrrr}
\hline \multicolumn{1}{c}{ Jenis Reklame } & R (Jmlh) & S (Rp) & D (Wkt) & \multicolumn{1}{c}{ Pr (\%) } & \multicolumn{1}{c}{ Jumlah (Rp) } \\
\hline Megatron/Videotron & 2 & 16.200 .000 & 1 tahun & 20 & 6.480 .000 \\
Reklame Bando & 85 & 23.040 .000 & 1 tahun & 20 & 391.680 .000 \\
Reklame Bilboard & 1586 & 15.120 .000 & 1 tahun & 20 & 4.796 .064 .000 \\
Reklame Neon Box & 295 & 2.400 .000 & 1 tahun & 20 & 141.600 .000 \\
Reklame Spanduk & 821 & 5.400 & 1 hari & 20 & 886.680 \\
Reklame Baliho & 240 & 21.600 & 1 hari & 20 & 1.036 .800 \\
Total Reklame & 3.029 & & & Total Potensi & 5.337 .747 .480 \\
\hline
\end{tabular}

Sumber: Data diolah

Tabel 4 dapat dilihat bahwa pada tahun 2014 BPPRD Kota Jambi menerima sebanyak 3.029unit reklame yang terdiri dari reklame megatron sebanyak 2unit, reklame bando sebanyak 85unit, reklame billboard sebanyak 1.586 unit, reklame neon box 295 unit,reklame spanduk sebanyak 821 unit sedangkan reklame baliho sebanyak 240 unit. Adanya jumlah reklame tersebut menggambarkan jumlah potensi yang dapat dijadikan sebagai sumber pendapatan pajak reklame oleh BPPRD Kota Jambi untuk tahun 2014 sebesar Rp.5.337.747.480. 
Tabel 5

Hasil Perhitungan Potensi Pajak Reklame Tahun 2015

\begin{tabular}{lrrrrr}
\hline \multicolumn{1}{c}{ Jenis Reklame } & R (Jmlh) & S (Rp) & D (Wkt) & Pr (\%) & \multicolumn{1}{c}{ Jumlah (Rp) } \\
\hline Megatron/Videotron & 3 & 16.200 .000 & 1 tahun & 20 & 9.720 .000 \\
Reklame Bando & 87 & 23.040 .000 & 1 tahun & 20 & 400.896 .000 \\
Reklame Bilboard & 1.809 & 15.120 .000 & 1 tahun & 20 & 5.470 .416 .000 \\
Reklame Neon Box & 320 & 2.400 .000 & 1 tahun & 20 & 153.600 .000 \\
Reklame Spanduk & 970 & 5.400 & 1 hari & 20 & 1.047 .600 \\
Reklame Baliho & 560 & 21.600 & 1 hari & 20 & 2.419 .200 \\
Total Reklame & 3.749 & & Total Potensi & 6.038 .098 .800 \\
\hline
\end{tabular}

Sumber: Data diolah

Tabel 5 dapat dilihat bahwa pada tahun 2015 BPPRD Kota Jambi menerima sebanyak 3.749unit reklame yang terdiri dari reklame megatron sebanyak 3 unit, reklame bando sebanyak 87 unit, reklame billboard sebanyak 1.809 unit, reklame neon box 320 unit, reklame spanduk sebanyak 970 unit sedangkan reklame baliho sebanyak 560 unit. Adanya jumlah reklame tersebut menggambarkan jumlah potensi yang dapat dijadikan sebagai sumber pendapatan pajak reklame oleh BPPRD Kota Jambi untuk tahun 2015 sebesar Rp.6.038.098.800,-

Tabel 6

Hasil Perhitungan Potensi Pajak Reklame Tahun 2016

\begin{tabular}{lrrrrr}
\hline \multicolumn{1}{c}{ Jenis Reklame } & R (Jmlh) & S (Rp) & D (Wkt) & Pr (\%) & Jumlah (Rp) \\
\hline Megatron/Videotron & 5 & 16.200 .000 & 1 tahun & 20 & 16.200 .000 \\
Reklame Bando & 96 & 23.040 .000 & 1 tahun & 20 & 442.368 .000 \\
Reklame Bilboard & 2.645 & 15.120 .000 & 1 tahun & 20 & 7.998 .480 .000 \\
Reklame Neon Box & 378 & 2.400 .000 & 1 tahun & 20 & 181.440 .000 \\
Reklame Spanduk & 986 & 5.400 & 1 hari & 20 & 1.064 .880 \\
Reklame Baliho & 821 & 21.600 & 1 hari & 20 & 3.546 .720 \\
Total Reklame & 4.931 & & & Total Potensi & 8.643 .099 .600 \\
\hline
\end{tabular}

Sumber: Data diolah BPPRD Kota Jambi

Tabel 6 dapat dilihat bahwa pada tahun 2016 BPPRD Kota Jambi menerima sebanyak 4.931 unit reklame yang terdiri dari reklame megatron sebanyak 5 unit, reklame bando sebanyak 96 unit, reklame billboard sebanyak 2.645 unit, reklame neon box 378, reklame spanduk sebanyak 986 unit dan reklame baliho sebanyak 821 unit . Adanya jumlah reklame tersebut menggambarkan jumlah potensi yang dapat dijadikan sebagai sumber pendapatan pajak reklame oleh BPPRD Kota Jambi untuk tahun 2016 sebesar Rp Rp.8.643.099.600. Setelah diketahui realisasi yang diterima BPPRD kota Jambi tahun 2014 hingga 2016 dengan hasil perhitungan potensi pajak reklame yang dihitung penulis, selanjutnya dilakukan perbandingan antara keduanya hasil manakah yang lebih besar. Untuk itu dapat dilihat dari tabel 5.7

Tabel 7

Perbandingan Potensi dan Realisasi Pajak Reklame di Kota Jambi Tahun 2014-2016

\begin{tabular}{llrrrrr}
\hline No & Tahun & \multicolumn{1}{c}{ Target (Rp) } & Realisasi (Rp) & Persen (\%) & \multicolumn{1}{c}{ Potensi (Rp) } & Persen (\%) \\
\hline 1 & 2014 & 7.500 .000 .000 & 5.270 .552 .970 & 70,27 & 5.337 .747 .480 \\
2 & 2015 & 10.000 .000 .000 & 6.000 .440 .224 & 60,00 & 6.038 .098 .800 & 60,38 \\
3 & 2016 & 10.000 .000 .000 & 8.475 .131 .873 & 84,75 & 8.643 .099 .600 & 86,43 \\
& & Jumlah & $\mathbf{1 9 . 7 4 6 . 1 2 5 . 0 6 7}$ & $\mathbf{7 1 , 6 7}$ & $\mathbf{2 0 . 0 1 8 . 9 4 5 . 8 8 0}$ & $\mathbf{7 2 , 6 5}$ \\
\hline
\end{tabular}

Sumber: Data diolah BPPRD Kota Jambi

Gambar 1

Grafik Perbandingan Realisasi, Target, dan Potensi Pajak Reklame Kota Jambi Tahun 2014-2016

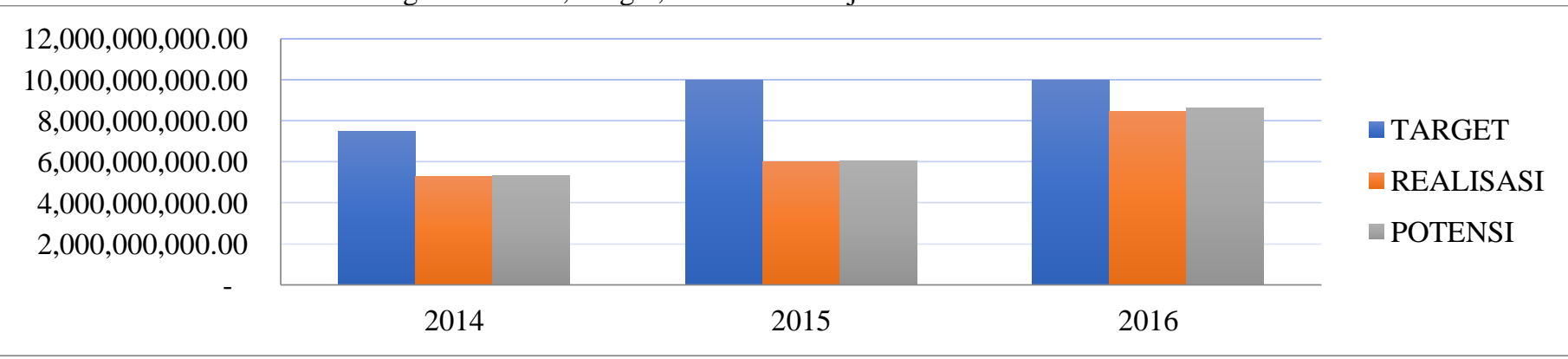

Sumber: Data diolah BPPRD Kota Jambi 
Tabel 7 dan Gambar 1 perbandingan diatas, disebutkan bahwa nilai potensi pajak reklame dari tahun 2014 hingga 2016 yang dihitung penulis selalu lebih tinggi jumlahnya dari realisasi yang diterima BPPRD kota Jambi. Selisih yang terjadi cukup jauh dari hasil perbandingan tersebut, dapat dilihat dari tabel tahun 2014 BPPRD memperoleh realisasi pajak reklame sebesar Rp.5.270.552.970 sedangkan perhitungan potensi pajak reklame tahun 2014 sebesar Rp.5.337.747.480. Potensi pajak reklame di Kota Jambi ternyata belum dapat digali secara optimal oleh BPPRD Kota Jambi. Jika dibandingkan antara potensi pajak reklame dengan target yang ditetapkan pemerintah ternyata hasilnya berbeda. Pemerintah terlalu tinggi menetapkan target pajak reklame tahun 2014 hingga 2016, sebenarnya potensi pajak reklame masih dibawah target yang telah ditetapkan pemerintah. Dalam menetapkan target pajak reklame, pemerintah diharapkan memperhatikan potensi pajak reklame yang ada setelah itu disinkronkan dengan target yang ditetapkan, tujuannya adalah supaya BPPRD menjadi terpacu untuk meningkatkan penerimaan pajak reklame. BPPRD Kota Jambi ternyata belum menggali potensi pajak reklame secara keseluruhan, masih ada potensi pajak yang belum tersentuh oleh pemerintah hal ini menyebabkan penerimaan pajak reklame yang diterima BPPRD belum optimal. Seperti yang diketahui dari data perbandingan diatas sebenarnya potensi pajak reklame Kota Jambi jauh lebih besar nilainya dibandingkan dengan realisasi yang diperoleh BPPRD Kota Jambi. Ketika disinggung tentang permasalahan- permasalahan yang ada yang menyebabkan potensi pajak belum tercapai, hal ini disebabkan: (1) masih ada wajib pajak yang belum terdaftar di kantor BPPRD Kota Jambi, tetapi mereka sudah mendirikan papan reklame tanpa izin; (2) reklame yang sudah habis masa pajaknya seharusnya sudah dilepas, tetapi masih ada juga kasus ditemukan bahwa reklame tersebut masih berdiri. Hal ini tentu saja merugikan pemerintah kota Jambi dari segi Pendapatan Asli Daerah (PAD), seandainya saja papan reklame tersebut yang habis masa pajaknya langsung dilepas atau kalau seandainya mau diperpanjang kembali urus izinnya dan bayar pajaknya kembali tentu tidak akan merugikan pemerintah dan pemasukan pun bertambah; (3) kasus dilapangan juga ditemukan kecurangan- kecurangan yang dilakukan biro reklame, seperti yang sering terjadi bahwa biro reklame sering mengganti- ganti iklan dilapangan tanpa sepengetahuan BPPRD, akibat ulah biro reklame inilah pemerintah menjadi rugi dari segi PAD demi keuntungan pribadi; (4) masih kurangnya pengawasan yang dilakukan pemerintah untuk terjun kelapangan memantau kecurangankecurangan yang terjadi mengenai pajak reklame, sehingga potensi yang diperoleh BPPRD belum maksimal; dan (5) sumber daya manusia sebenarnya masih kurang di BPPRD kota Jambi untuk selalu memantau ke lapangan, karena jumlah reklame yang begitu banyak jumlahnya mencapai puluh ribuan tidak sebanding dengan petugas yang ada. Ternyata pemerintah kewalahan menghadapi hal ini dan menyebabkan banyak yang berbuat curang.

\section{SIMPULAN}

Hasil penelitian analisis potensi pajak reklame di Kota Jambi adalah sebagai berikut:

a. Bahwa setelah dilakukan perhitungan, perbandingan antara realisasi yang diterima BPPRD Kota Jambi dengan potensi pajak reklame yang ada, ternyata potensi pajak reklame yang ada masih diatas realisasi yang diterima BPPRD, nilainya pun dari tahun 2014 hingga 2016 selalu lebih tinggi dibandingkan realisasi yang diterima BPPRD Kota Jambi. Hal ini terjadi karena masih ada potensi pajak yang belum tersentuh oleh BPPRD, masih ada potensi pajak yang belum terjangkau disebabkan banyaknya kendala.

b. Pada saat potensi pajak reklame dibandingkan dengan target yang ditetapkan pemerintah hasilnya ternyata dari tahun 2014 hingga 2016 pemerintah terlalu tinggi menetapkan target pajak reklame sebenarnya potensi pajaknya tidak sampai sebesar target yang ditetapkan pemerintah tersebut,

\section{DAFTAR PUSTAKA}

Achmad Tjahjono. 2009. Akuntansi Suatu Pengantar 2, Cetakan 1. Yogyakarya: Ganbika.

Abdul, Halim.2003. Analisis Investasi. Edisi Kedua. Jakarta : Salemba Empat.

Devas, Nick, 1989, Keuangan Pemerintah Daerah di Indonesia, UI, Press, Jakarta

Dumairi. 1998. Perekonomian Indonesia. Jakarta: Erlangga.

Ghozali, Imam. 2006. Aplikasi Analisis Multivariate Dengan Program SPSS. Cetakan Keempat. Semarang: Badan Penerbit Universitas Diponegoro.

Gujarati, Damodar, 1999, Ekonometrika Dasar, Erlangga, Jakarta.

Jhingan M.L. 1999; Ekonomi Pembangunan dan Perencanaan, Raja Grafindo Persada Jakarata. Jakarta.

Marihot. 2005. Pajak Daerah, Retribusi Daerah, Jakarta. Pantialon Lestari Raya

Grafindo.

Mankiw, N. Gregory (2003). Teori Makroe konomi Edisi Kelima. Terjemahan. Jakarta: Penerbit Erlangga.

Moh. Nazir, 1999, Metode Penelitian, Jakarta; Ghalia Indonesia.

Musgrave, 1993. Keuangan Negara Dalam Teori dan Praktek, edisi V ,Erlangga, Jakarta.

Prakosa, Bambang Kesit. 2005. Pajak dan Retribusi Daerah edisi revisi. Yogyakarta. UII Press.

Peraturan Daerah Kota jambi No. 5 Tahun 2011 Tentang Pajak Daerah.

Peraturan Daerah Kota jambi No. 2 Tahun 2005 Tentang Pajak Reklame. 
Sutrisno. 2002. Studi Manajemen Laba (Earnings Management) Evaluasi Pandangan Profesi Akuntansi, Pembentukan dan Motivasinya.

Sugiyono. 2009. Metode Penelitian Bisnis. Bandung: Alfabeta.

Sudjana, Nana.(1999). Penilaian Hasil Proses Belajar Mengajar. Bandung : PT. Remaja Rosdakarya.

Sadono Sukirno, 2003, Pengantar Teori Makro Ekonomi, Edisi Kedua, PT

Raja Grafindo Persada, Jakarta.

Syuhada Sofian, 1997, Prospek dan Alternatif “Action Plan” Perpajakan Reklame dalam Mendongkrak Pendapatan Asli Daerah Studi Kasus Kodya Semarang, Gema Stikubank, Semarang.

Sutrisno P.H, 1983, Dasar - Dasar Kebijakan Ekonomi dan Kebijakan Fiskal,

BPFE, Yogyakarta.

Umi, Narimawati. (2010) Metodologi Penelitian: Dasar Penyusun Penelitian Ekonomi.Jakarta:penerbit Genesis.

Undang-undang Nomor 28 Tahun 2009 Tentang Pajak Daerah dan Retribusi Dearah.

Undang-undang Nomor 14 Tahun 2008 Tentang Tata Cara Perizinan Reklame. 